\title{
Utilization of agricultural residues as animal feeds for fattening sheep in Saudi Arabia
}

\author{
H. Al Tonobey \& H. M. El Shaer \\ Al Khalidiah Farm-Tebrak, Kingdom of Saudi Arabia
}

\begin{abstract}
Due to diversified agricultural activities in Al Khalidiah Farm, SA (2500 hectares), more than 7000 ton/year of different agricultural residues (AGR) are produced annually. The study consisted of two trials; the first one aimed to evaluate the chemical composition and nutritive value of some selected AGR to be used as animal feeds and to evaluate the effect of dehydration treatments on their chemical and microbiological analysis. The second trial was conducted to investigate the impact of feeding combinations of five feed ingredients made from the tested agriculture residues on the performance of fattened sheep lambs. During the first trial, seven types of AGR (one ton each) were collected namely: 1- Landscape mowing grasses (LMG), 2- Mixed ornamental plants residues (MOPR) , 3- Olive trees pruning (OTP), 4- Citrus tree pruning (CTP), 5- Date trees pruning(DTP), 6- Horse stable grasses residues (HSGR) and 7- Green houses by-products (GHBP). These AGR were air-dried, ground and tested for preliminary chemical composition and nutritive value. Five tons from each of new AGR materials were air -dried, ground then heated in a drying drum at $90^{\circ} \mathrm{C}$ for 15 minutes. Five samples were taken, randomly, from each air- dried material and after being heated to evaluate the impact of heating on the chemical analyses and microbiological parameters of the tested materials. During the second trial, five rations from the tested AGR ingredients were formulated and offered to fifty weaned lambs ( 2 month- old and averaged $17.0 \pm 0.73 \mathrm{Kg}$ body weight) divided randomly in five groups (10 lambs each) in a group feeding system for a 9-week fattening period. The rations were offered ad libitum and consisted of: 1- LMG, 2- MOPR, 3- HSGR, 4- A mixture of olive tree pruning mixed with orange fruits by-products (OTPOF) for the four groups: R1, R2, R3, R4, respectively while the control group (R5) was offered Alfalfa hay. All groups were offered the Concentrate Feed Mixtures (CFM) at $60 \%$ of the total ration while roughages were offered at $40 \%$. Animals were weighed at the beginning of the experiment
\end{abstract}


and biweekly. Feeding allowances were adjusted biweekly according to body weight changes. Voluntary feed intake, feed conversion and feeding costs were determined. Representative samples of the feed ingredients were tested for chemical, pathogens and microbiological analysis.

Results of the first trial indicated that all AGR feed ingredients appeared to be nutritious since they contained enough concentration of nutrients to cover animal nutritional requirements. Crude protein content varied among the feed ingredients and ranged from $6.53 \%$ (CTP) to $19.77 \%$ (LMG). Heating treatment, generally, did not affect $(\mathrm{P}>0.05)$ all nutrients concentration nor microbiological parameters of all tested feed ingredients. Results of the second trial showed that animals fed R2 followed by R1 recorded the highest average daily gain of 283 and $280 \mathrm{~g} /$ day, respectively as a reflection of their high feed intakes. Feed costs of rations R1 and R2 were comparable and showed the lowest feed costs per one kilogram gain (SR 1.35 and 1.36, respectively) while the control ration (R5) recorded the highest feed cost (SR 2.23). It is shown that lambs of R3 were more efficient in feed conversion (3.52 gm DM/gm gain) than the other tested rations. It could be concluded that using AGR in feeding animals is economic and has a positive impact on productive performance feeding costs of fattened lambs.

Keywords: sheep, fattening, intake, feed efficiency, agricultural residues, environment, heating treatments, chemical composition.

\section{Introduction}

Over the last few years, Saudi Arabia $(2,150,000 \mathrm{sq} \mathrm{km})$ has realized the advantages of agricultural residues (AGR) on the economy, industry and environment. With the rapid increase in cultivation of sizable lands in Saudi Arabia (SA) as well as animal feeds and fertilizer costs [1]. There has been a rapid realization that significant environmental and financial benefits can be achieved through proper utilization of AGR. Presently, there are more than 1.6 million tons of AGR produced annually in the Kingdom, approximately $28 \%$ of which comes mainly from date palm in addition to other tree crops [2]. Certain private agricultural companies sensed the importance of AGR and have already started new ventures to exploit these materials on sustainable basis. For instances, due to diversified agricultural activities in Al Khalidiah Farm (as one of the pioneer model farms, 2500 ha. in SA), around 7000 ton/year of different AGR are produced annually. On the other hands, the deficiency of animal feeds in SA reaches more transforming AGR into animal feedstuffs would help a great deal in overcoming this deficiency [1]. Most AGR have high contents of fiber and not easily to be digested in addition to low content of crude protein $[3,4]$. To improve the quality and utilization of such materials by animals, several physical and mechanical methods should be applied such as: chopping, shredding, grinding, heating $[5,6]$. Some mechanical methods or dehydration processes have proved to improve feed digestibility and efficiency for ruminants $[3,7,8]$.

The study was conducted to investigate the impact of fattening weaned sheep lambs on five non-conventional feed ingredients made from the available AGR at Al Khalidiah Farm, Saudi Arabia. Feed costs in comparison with the 
traditional feed ingredients (based on alfalfa and Concentrate feed mixture) was also determined.

\section{Materials and methods}

The study was conducted at Al Khalidiah Farm (120 km west of Riyadh) during summer 2009. It consisted of two trials. The first trial aimed to collect, identify the proper organic materials then to evaluate the chemical and microbiological analysis of the selected materials affected by dehydration processes. The second trial was conducted to evaluate the voluntary feed intake and feed efficiency of the formulated fattened rations based on AGR fed to Nagdi sheep during a 9week fattening period.

\subsection{The first trial}

Around one tone from each of seven agriculture residues types was collected for preliminary chemical analyses and nutritive value to be used later as animal feed ingredients in fattened rations formulation. The main selected AGR ingredients were as follows: 1- Landscape mowing grasses (LMG), 2- Mixed ornamental plants residues (MOPR, the seasonal flowering plants for ornamental), 3- Citrus tree pruning (CTP), 4- Olive trees pruning (OTP), 5- Olive trees pruning - orange fruits (OTPOF), 6- Green houses by- products (GHBP) and 7- Horse-stable grasses residues (HSGR). Each material was air-dried separately, and then chopped and ground $(8 \mathrm{~mm})$ and three composite samples were collected from each material and kept for the chemical composition analyses and nutritive value determination. Around five tons from each material were collected again, chopped and ground $(8 \mathrm{~mm})$ and air-dried then heated into a drying drum at $90^{\circ} \mathrm{C}$ for 10 minutes. Five samples were taken, randomly, from each air-dried feed materials before and after being heated to evaluate the impact of heating on the chemical analysis and microbiological parameters of tested materials.

\subsection{The second trial}

Five fattening rations were formulated based on the tested AGR to be offered for five equal numbers groups of 2-month old weaned Nagdi sheep lambs (10 animals / group) averaged $17.0 \pm 0.73 \mathrm{Kg}$ body weight. The rations (R1, R2, R3 and R4) were formulated from the following agriculture residues feed ingredients: 1. LMG, 2. MOPR, 3. HSGR and 4. OTPOF. The control group (R5) was fed on alfalfa hay. The formulated rations are illustrated in Table 1. All animal groups were offered the Concentrate Feed Mixtures (CFM) as an energy supplementary feeding (Metabolizable energy $=5.54 \mathrm{MJ} / \mathrm{Kg} \mathrm{DM}$ ). The CFM consisted of $30 \%$ cotton seed cake, $47 \%$ yellow corn, $20 \%$ wheat bran, $2 \%$ limestone and $1 \%$ common salt. The fattening diets were given to animals at $60 \%$ concentrates (CFM) to $40 \%$ roughage ratio. 
Table 1: $\quad$ Experimental rations formulation.

\begin{tabular}{|c|c|c|c|c|c|}
\hline Feed ingredients & R1 & $\mathrm{R} 2$ & R3 & R4 & R5 \\
\hline \multicolumn{6}{|l|}{ Roughages: } \\
\hline 1. Landscape mowing grasses (LMG), $\%$ & 40 & 20 & 20 & 15 & - \\
\hline 2.Mixed ornamental plants residues (MOPR), $\%$ & - & - & - & 5 & - \\
\hline 3. Horse- stable grasses residues (HSGR), $\%$ & - & - & - & 5 & - \\
\hline 4. Olive trees pruning - orange fruits (OTPOF), $\%$ & - & 20 & - & 15 & - \\
\hline 5. Alfalfa Hay,\% & - & - & 20 & - & 40 \\
\hline Crude protein $(\mathrm{CP}), \%$ of roughages & 7.44 & 5.48 & 6.98 & 5.38 & 6.52 \\
\hline $\mathrm{ME} *(\mathrm{MJ} / \mathrm{Kg} \mathrm{DM})$ of roughages & 0.840 & 0.822 & 0.804 & 0.809 & 0.76 \\
\hline Concentrate Feed Mixture (CFM), $\%$ & 60 & 60 & 60 & 60 & 60 \\
\hline Total crude protein of ration (CP), $\%$ & 15.36 & 13.40 & 14.90 & 13.30 & 14.4 \\
\hline *Total ME of ration(MJ/Kg DM) & 4.164 & 4.146 & 4.128 & 4.133 & 4.09 \\
\hline
\end{tabular}

*Metabolizable energy

All dietary roughages were offered to animals ad libtum during the fattening trial. The amounts of feed offered and refused were recorded to calculate the actual voluntary daily intake for each animal group. Animals were individually weighed at the beginning of the experiment and every other week. Feeding allowances were adjusted biweekly according to body weight changes for lambs during the fattening period. All animals were allowed to drink fresh water free choice. Daily offered feeds, daily feeds refusals, bi-weekly live body weight changes, feed costs and feed efficiency of fattened animals fed the formulated rations were measured and recorded for each animal group.

The representative samples of all feed ingredients were tested for proximate chemical analysis [9] and microbiological analysis which included total viable bacterial counts $(\mathrm{cfu} / \mathrm{g})$, molds and yeasts counts $(\mathrm{cfu} / \mathrm{g})$, total coliform (MPN/100g), faecal coliform (MPN/100g), salmonella detection (cfu/g) and mycotoxins detection $[10,11]$. Data were subjected to the statistical analysis system according to SAS [12]. Differences in mean values among groups were compared by Duncan's Multiple Range Test [13].

\section{Results and Discussion}

\subsection{First trial}

\subsubsection{Chemical composition and nutritive values of the tested agriculture residues}

Data on the chemical composition and metabolizable energy (ME) content $(\mathrm{MJ} / \mathrm{Kg}$ dry matter) of the selected feed ingredients based on AGR namely 1- LMG, 2- MOPR, 3- CTP, 4- OTP, 5- OTPOF ,6- GHBP and 7- HSGR are summarized, on overall averages, in Table 2. 
Table 2: $\quad$ Chemical composition (\%, on dry matter basis) and metabolizable energy*(MJ/Kg dry matter) of the selected AGR.

\begin{tabular}{lllllllll}
\hline Feed materials & DM & OM & CP & CF & EE & ASH & NFE & ME \\
\hline Landscape mowing grasses (LMG) & & & & & & & & \\
Mixed ornamental plants residues (MOPR) & 94.28 & 87.60 & 18.6 & 24.00 & 1.59 & 12.40 & 43.41 & 2.10 \\
Citrus trees pruning (CTP) & 96.29 & 86.86 & 6.53 & 37.05 & 1.00 & 13.14 & 42.28 & 1.71 \\
Olive trees pruning (OTP) & 90.44 & 91.10 & 10.88 & 21.42 & 1.67 & 8.90 & 57.13 & 2.07 \\
Olive trees pruning - orange fruits (OTPOF) & 92.00 & 92.55 & 8.78 & 27.70 & 1.60 & 7.45 & 54.47 & 2.01 \\
Green houses by- products GHBP) & 95.74 & 89.00 & 12.10 & 34.70 & 1.25 & 11.00 & 40.95 & 1.90 \\
Horse- stable grasses residues (HSGR) & 95.85 & 89.80 & 12.00 & 33.67 & 1.40 & 10.20 & 42.73 & 1.93 \\
\hline
\end{tabular}

*ME is calculated [14]

DM: dry matter; OM: organic matter; $\mathrm{CP}$ : crude protein: $\mathrm{CF}$ : crude fiber: EE: ether extracts: NFE: nitrogen free extracts: ME: metabolizable energy.

CTP could be considered as a poor dietary roughage due to its low level of $\mathrm{CP}(6.53 \%)$ and metabolizable energy (ME) with high crude fiber $(37.05 \%)$ that might reduce its nutritive value, digestion and utilization $[5,6]$. On the other hands, LMG appeared to be very nutritious since it contained the highest $\mathrm{CP}$ and ME in comparison with the other AGR. In general, all the tested AGR, except CTP, contained enough nutrients concentrations to cover the nutritional requirements of ruminant and small ruminants animals according to the recommendations of [15]. Such materials could be used successfully as good quality roughages $[3,6]$. Therefore, it is suggested to formulate the fattening rations based on LMG, MOPR, HSGR, OTP, and OTPOF in the study.

\subsubsection{Effect of dehydration treatment on chemical composition and microbiological parameters of the tested AGR}

The average values of chemical and microbiological parameters of the suggested five AGR: 1-LMG, 2- MOPR, 3- HSGR, 4- OTP, 5- OTPOF as affected by dehydration treatments are summarized in Table 3. Regardless of the dehydration treatments, most of the nutrients were influenced significantly $(\mathrm{P}<0.05)$ by the AGR types. Dehydration of the AGR using heating treatments showed varied influences on their chemical composition and microbiological parameters. It seems that although some of chemical nutrients were slightly changed by heating treatment, most of nutrients in the tested materials were not affected significantly by the dehydration treatments. For instances, CF and ash contents of the heated OTP and OTPOF were slightly higher compared to those of the air-dried ones whereas OM and nitrogen free extracts (NFE) values were decreased by heating treatment. Similarly, ether extracts (EE) of the air-dried LMG and MOPR decreased $(\mathrm{P}<0.05)$ by heating. Regardless of such little changes of nutrient concentrations, the air-dried AGR may be sufficient enough to cover the animal nutritional requirements [15].

Data on microbiological analysis of the five AGR (Table 3) revealed that all the measured parameters (Total coliform count, Fecal coliform count, Yeast and mold count, Salmonella spp, Staph aureus, Bacillus cereus, and Aflatoxins) were not affected by heating treatment and they were in the normal ranges without any expected harmful effects $[10,11,16]$. Based on the above mentioned 
facts, it was suggested that the tested air- dried AGR materials should be used for formulating the dietary rations for the fattened lambs in the study. Above all, it would decrease the cost of feeding due to saving the costs of energy for heating treatment.

Table 3: Proximate chemical composition (\% on dry matter basis) and microbiological parameters of the five AGR* affected by dehydration treatments.

\begin{tabular}{|c|c|c|c|c|c|c|c|c|c|c|}
\hline Parameters & & & $\mathrm{r}-\operatorname{dried} \mathrm{AC}$ & & & & & Feated $A G$ & & \\
\hline & LMG & MOPR & HSGR & ОТР & OTPOF & LMG & MOPR & HSGR & OTP & $\begin{array}{l}\text { OTPO } \\
\mathrm{F}\end{array}$ \\
\hline Dry matter & $91.40 \mathrm{ab}$ & $90.19 \mathrm{ab}$ & 96.48a & $87.51 \mathrm{ab}$ & $91.83 \mathrm{ab}$ & $98.92 \mathrm{a}$ & $97.10 \mathrm{a}$ & $98.60 \mathrm{a}$ & $99.44 \mathrm{a}$ & $97.45 \mathrm{a}$ \\
\hline Crude protein & $19.77 \mathrm{a}$ & $12.72 \mathrm{~b}$ & $12.76 \mathrm{~b}$ & $10.58 \mathrm{bc}$ & $8.81 \mathrm{bc}$ & $20.10 \mathrm{a}$ & $13.64 \mathrm{~b}$ & $12.79 \mathrm{~b}$ & $10.88 \mathrm{bc}$ & $9.63 \mathrm{bc}$ \\
\hline Crude fiber & $22.40 \mathrm{~b}$ & $20.74 \mathrm{~b}$ & $35.65 a$ & $17.25 \mathrm{c}$ & $28.35 \mathrm{ab}$ & $24.61 \mathrm{~b}$ & $22.66 \mathrm{~b}$ & $34.07 \mathrm{a}$ & $21.42 \mathrm{~b}$ & $\begin{array}{l}27.50 \mathrm{a} \\
\mathrm{b}\end{array}$ \\
\hline Ether Extract & $2.18 \mathrm{a}$ & $1.71 \mathrm{ab}$ & $1.00 \mathrm{c}$ & $1.76 \mathrm{ab}$ & $1.44 \mathrm{bc}$ & $1.50 \mathrm{~b}$ & $1.22 \mathrm{bc}$ & $1.32 \mathrm{~b}$ & $1.67 \mathrm{ab}$ & $1.72 \mathrm{a}$ \\
\hline Organic matter & $86.89 \mathrm{ab}$ & $83.26 \mathrm{ab}$ & $89.78 \mathrm{a}$ & $92.69 \mathrm{a}$ & $93.55 \mathrm{a}$ & $86.78 \mathrm{ab}$ & $80.16 \mathrm{~b}$ & $88.45 \mathrm{ab}$ & $91.10 \mathrm{a}$ & $89.50 \mathrm{a}$ \\
\hline Ash & $13.11 \mathrm{~b}$ & $16.74 \mathrm{a}$ & $10.22 \mathrm{~b}$ & $7.31 \mathrm{c}$ & $6.45 \mathrm{c}$ & $13.22 \mathrm{~b}$ & $19.84 \mathrm{a}$ & $11.55 \mathrm{~b}$ & $8.90 \mathrm{c}$ & $10.50 \mathrm{~b}$ \\
\hline NFE & $42.54 \mathrm{c}$ & $48.09 \mathrm{ab}$ & $40.37 \mathrm{c}$ & 63.10a & $54.95 \mathrm{a}$ & $40.57 \mathrm{~b}$ & $42.64 \mathrm{~b}$ & $40.27 \mathrm{~b}$ & 57.13a & $\begin{array}{l}50.56 \mathrm{a} \\
\mathrm{b}\end{array}$ \\
\hline Aflatoxins & $\mathrm{ND}^{* * *}$ & ND & ND & ND & ND & ND & ND & ND & ND & ND \\
\hline \begin{tabular}{|cc} 
Total & coliform \\
count & \\
\end{tabular} & $1.2 \times 10^{6}$ & $1.1 \times 10^{5}$ & $2.6 \times 10^{6}$ & $2.8 \times 10^{5}$ & $2.7 \times 10^{4}$ & $2.2 \times 10^{4}$ & $7.0 \times 10^{3}$ & $4.1 \times 10^{4}$ & $1.8 \times 10^{3}$ & $9.5 \times 10^{2}$ \\
\hline \begin{tabular}{|cc}
\begin{tabular}{|} 
Fecal \\
count
\end{tabular} & coliform \\
\end{tabular} & $3.0 \times 10$ & $8.0 \times 10$ & $5.0 \times 10$ & $1.0 \times 10$ & $<10$ & $1.0 \times 10$ & $3.0 \times 10$ & $<10$ & $<10$ & $<10$ \\
\hline Yeast \& mold count & $2.6 \times 10^{6}$ & $4.3 \times 10^{6}$ & $3.1 \times 10^{6}$ & $4.8 \times 10^{6}$ & $6.0 \times 10^{5}$ & $3.3 \times 10^{4}$ & $3.7 \times 10^{4}$ & $5.3 \times 10^{4}$ & $2.4 \times 10^{4}$ & $8.4 \times 10^{3}$ \\
\hline $\begin{array}{c}\begin{array}{c}\text { lmonella } \\
\mathrm{cfu} / \mathrm{gm}\end{array} \\
\end{array}$ & ND & ND & ND & ND & ND & ND & ND & ND & ND & ND \\
\hline \begin{tabular}{|ll}
$\begin{array}{l}\text { Staph } \\
\text { cfu/gm }\end{array}$ & aureus, \\
\end{tabular} & ND & ND & ND & ND & ND & ND & ND & ND & ND & ND \\
\hline $\begin{array}{l}\text { Bacillus cereus, } \\
\text { cfu/gm }\end{array}$ & ND & ND & ND & ND & ND & ND & ND & ND & ND & ND \\
\hline $\begin{array}{l}\text { Clostridium spp, } \\
\mathrm{cfu} / \mathrm{gm}\end{array}$ & ND & ND & ND & ND & ND & ND & ND & ND & ND & ND \\
\hline
\end{tabular}

*1-Landscape mowing grasses (LMG), 2- Mixed ornamental plants residues (MOPR), 3- Horse-stable grasses residues (HSGR), 4- Olive trees pruning (OTP), 5- A mixture of olive tree pruning mixed with orange fruits by-products (OTPOF).

**a, b, c; means with different letters in the same row differ significantly $(\mathrm{P}<0.05)$, otherwise no significant differences.

***ND: Not Detected.

\subsection{Second trial}

\subsubsection{Effect of feeding fattening rations based on AGR on the performance of fattened Nagdi lambs}

The proximate analysis of the feed ingredients used for formulating the fattening rations is shown in Table 4. The five feed ingredients based on AGR were: 1-LMG, 2- MOPR, 3- HSGR, 3- OTP, 5- OTPOF. Alfalfa hay was used as good quality roughage for feeding the control group (R5) and to be compared with 
feeding AGR feed ingredients for animals in R1, R2, R3 and R4 as indicated earlier in Table 1 .

It is noticed that LMG attained the highest CP level (19.77\%) and metabolizable energy (2.10 MJ/Kg DM) while MOPR and HSGR contained similar levels of CP (around 12.7\%). Although OTPOF showed the lowest CP level $(8.81 \%)$, it contained higher metabolizable energy $(2.01 \mathrm{MJ} / \mathrm{Kg} \mathrm{DM}$, as shown in Table 2).

Based on data in Tables 1, 2 and 4, the total crude protein of the fattening rations were $15.36,13.40,14.90,13.30$ and $14.44 \%$ for R1, R2, R3, R4 and R5, respectively; the corresponding figures for metabolizable energy were 4.164, 4.146, 4.128, 4.133 and 4.092 $\mathrm{MJ} / \mathrm{Kg} \mathrm{DM}$ in respective orders (Table 1).

Table 4: Chemical composition (\%, on dry matter basis) of the feed ingredients used for formulating the fattening rations.

\begin{tabular}{|c|c|c|c|c|c|c|c|}
\hline Feed ingredients & DM & $\mathrm{OM}$ & $\mathrm{CP}$ & $\mathrm{CF}$ & $\mathrm{EE}$ & ASH & NFE \\
\hline $\begin{array}{l}\begin{array}{l}\text { Landscape mowing } \\
\text { (LMG) }\end{array} \\
\text { grasses } \\
\end{array}$ & 91.4 & 86.89 & 19.77 & 22.4 & 2.18 & 13.11 & 42.54 \\
\hline $\begin{array}{r}\text { Mixed ornamental plants } \\
\text { residues (MOPR) }\end{array}$ & 90.19 & 83.26 & 12.72 & 20.74 & 1.71 & 16.74 & 48.09 \\
\hline $\begin{array}{r}\text { Horse stable grasses residues } \\
\text { (HSGR) }\end{array}$ & 96.48 & 98.78 & 12.76 & 35.65 & 1.00 & 10.22 & 40.37 \\
\hline $\begin{array}{l}\text { Olive trees pruning mixed } \\
\text { with orange fruits by- products } \\
\text { (OTPOF) }\end{array}$ & 91.83 & 93.55 & 8.81 & 28.35 & 1.44 & 6.45 & 54.95 \\
\hline Alfalfa Hay (AH) & 91.55 & 85.83 & 16.3 & 25.86 & 1.96 & 14.17 & 41.71 \\
\hline $\begin{array}{r}\text { Concentrate Feed Mixture } \\
\text { (CFM) }\end{array}$ & 90.9 & 92.29 & 13.2 & 10.15 & 2.32 & 7.71 & 66.62 \\
\hline
\end{tabular}

Concerning voluntary feed intake ( $\mathrm{Kg} \mathrm{DM} /$ day) of the fattened lambs (Figure 1), it was noticed that animals fed R1, R2 and R3 started to consume the experimental rations gradually then the consumption was increased rapidly afterwards up to the end of the period ( 9 weeks) compared to those fed the control ration. Such trends were occurred due to the inclusion of LMG in the rations at 40, 20, 20 and $15 \%$, in $\mathrm{R} 1, \mathrm{R} 2, \mathrm{R} 3$ and $\mathrm{R} 4$, respectively. The LMG ingredient was consumed very fast before any other feed ingredients indicating high palatability. By the end of the fattening trial, the highest voluntary feed intake (VFI) from the roughage materials was reordered for animals in R2 then followed by those in R4, R1 and R3 in respective orders. The VFI of alfalfa hay in the control (R5) showed the lowest value indicating that all AGR feed ingredients were more acceptable to all animal groups rather than alfalfa. 


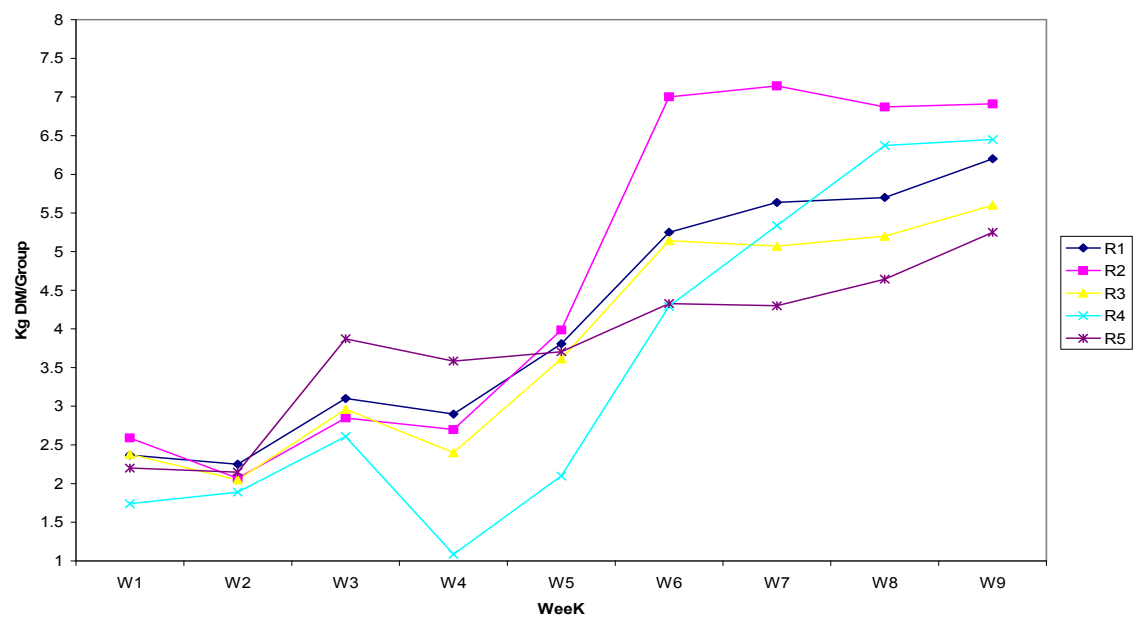

Figure 1: $\quad$ Voluntary feed intake ( $\mathrm{Kg} \mathrm{DM} /$ day) of the fattened lambs.

\section{Body weight changes $(\mathrm{Kg})$}

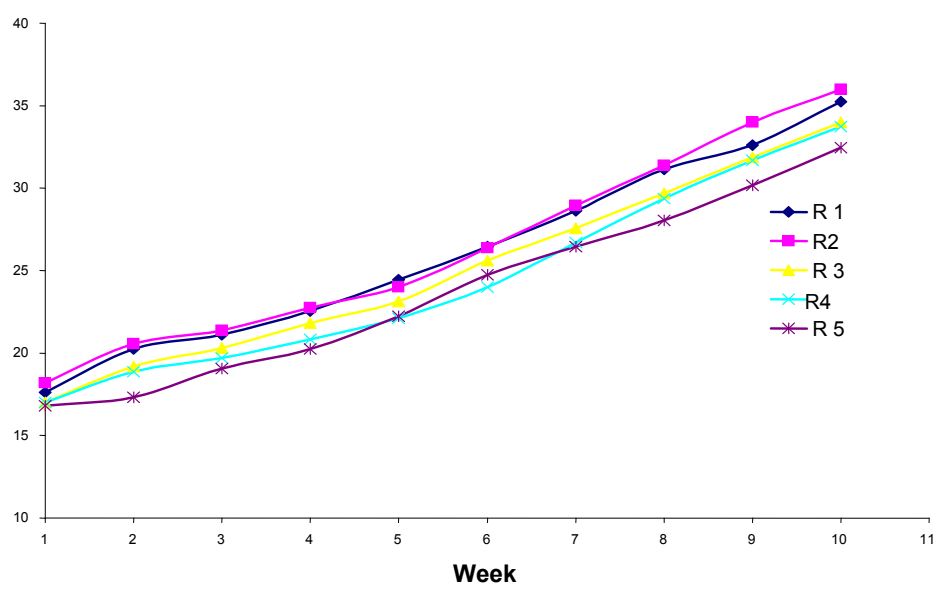

Figure 2: $\quad$ Body weight changes $(\mathrm{kg} / \mathrm{head})$ of the fattened lambs.

Live body weigh changes were affected to some extents by the patterns of VFI of AGR feed ingredients where the highest body gain was recoded for animals fed R2 and R1 (17.8 and $17.6 \mathrm{~kg}$, respectively) followed by those fed R3 
(17 kg), R4 (16.8 kg) and the control group (R5) recorded the lowest gain (15.6 $\mathrm{kg}$ ) without any significant $(\mathrm{P}>0.05)$ differences as show in Figure 2. These results are similar to those obtained on sheep fed on some AGR such as vegetable by products, ground date seeds and fruit by products $[2,6]$.

As expected, average daily gain (ADG, g/head/day) of the fattened lambs tended to increase rapidly after the fourth week of feeding due to the increase in VFI of AGR feed ingredients as shown in Figure 3. Animals fed R2 and R1 recorded the greatest ADG (283 and $280 \mathrm{~g} / \mathrm{head} /$ day, respectively and was higher approximately $12 \%$ than that of the control group ( $248 \mathrm{~g} / \mathrm{head} / \mathrm{day})$. Animals in R3 and R4 showed comparable weight gain ( 270 vs. $260 \mathrm{~g} /$ head/day).

The patterns of body weight changes and ADG, consequently, were a reflection of both dry matter intake(DMI) and the nutritive values of the fattening rations where animals fed AGR feed ingredients (R1, R2, R4 and R5) tended to consume $\mathrm{CP}$ and ME more than those fed the control ration (R1) as shown in Table 1 and Figure 1. These findings are in close agreement with those reported by many investigators $[4,7,8,17]$.

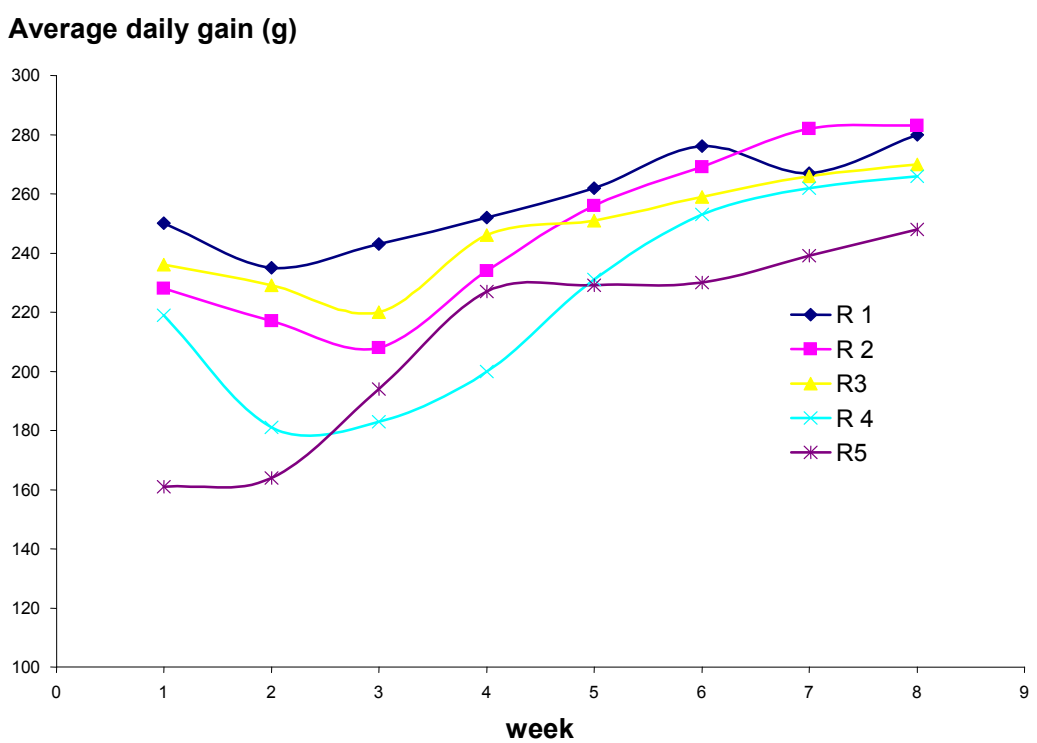

Figure 3: Average daily gain ( $\mathrm{g} /$ head/ day) of the fattened lambs.

Data on feed efficiency and feed costs (Table 5) reported that feed efficiency ranged from 3.49 (R5) to $3.73 \mathrm{~g} \mathrm{DM} / \mathrm{g}$ gain (R2). In comparison between the four AGR fattening rations with the control ration (R5), it appeared that feeding R1, R2, R3 and R4 would decrease the costs around SR 40, 39, 25 and 37, respectively. Therefore, feeding such AGR for fattened sheep would be more 
economic than feeding conventional expensive feed ingredients (e.g. alfalfa) which support the earlier results reported by many workers using AGR as feed materials for sheep and goats[3, 8, 17, 18].

Table 5: $\quad$ Body weight (BW) changes, average daily gain (ADG), dry matter intake (DMI) and feed efficiency and costs.

\begin{tabular}{|c|c|c|c|c|c|c|c|}
\hline Parameters & $\mathrm{R} 1$ & $\mathrm{R} 2$ & R3 & $\mathrm{R} 4$ & R5 & SE & **Significant \\
\hline Initial BW (kg) & 17.6 & 18.2 & 17.0 & 17.0 & 16.8 & 0.37 & n.s. \\
\hline Final BW (kg) & 35.3 & 36.0 & 34.0 & 33.8 & 32.4 & 1.05 & n.s. \\
\hline BW changes $(\mathrm{kg} / \mathrm{head})$ & 17.6 & 17.8 & 17.0 & 16.8 & 15.6 & 1.02 & n.s. \\
\hline ADG (g/head/ day) & 280 & 283 & 270 & 266 & 248 & 16.2 & n.s. \\
\hline \multicolumn{8}{|l|}{ DMI (g/head/ day) } \\
\hline Roughage & 390 & 402 & 283 & 342 & 318 & & \\
\hline CFM & 654 & 661 & 668 & 661 & 547 & & \\
\hline Total & 1044 & 1063 & 951 & 1003 & 865 & & \\
\hline \multicolumn{8}{|l|}{ Feed efficiency } \\
\hline g DM/g gain & 3.73 & 3.76 & 3.52 & 3.77 & 3.49 & & \\
\hline \multicolumn{8}{|l|}{ Feed costs } \\
\hline *SR / 1 kg gain & 1.35 & 1.36 & 1.67 & 1.40 & 2.23 & & \\
\hline
\end{tabular}

*SR: Saudi Riyal= US\$ 0. 27.

**n.s.: not significant at $5 \%$ probability level.

It is well known that the costs of animal feeding represent about $75 \%$ of the animal production investment, so consequently, animal products (meet, milk, etc,) would be produced at reasonable prices and the net revenue for livestock owners would be increased through feeding these ground AGR feed materials. Grinding the AGR leads to a reduction in particle size, and increase in surface area and density [17, 18]. Associated with these changes, an increase in voluntary intake, a reduction in digestibility and increase in the efficiency of the utilization of metabolizable energy are obtained [5]. Grinding led to an increase of $25 \%$ in voluntary intake, of $98 \%$ in daily live weight gain and of $36 \%$ improvement in conversion efficiency $[5,18]$.

\section{Conclusions}

It can be concluded that most of agriculture residues could play an important role in feeding animals due to their great nutritional potentiality particularly if such materials are processed through proper treatment as air-drying and grinding. Feeding such AGR for fattened sheep would be more economic than feeding conventional expensive feed ingredients (e.g. alfalfa). It is safe to recommend that $\mathrm{LMG}$ ) and/or OTPOF can be used successfully for formulating small ruminants feeds due their high palatability and nutritive values and on the other hands, the farms would be friendly environment. 


\section{References}

[1] El-Ghamdy, M. the use of agriculture residues in feed industry, Saudi Arabia. Proceedings of FAO Expert Consultation on the Utilization of Agricultural Residues. Cairo, Egypt, 6- 8 June, 2004, pp. 210-221, 2004.

[2] Mousa, H. Saudi Arabia Biotechnology Update .USDA Foreign Agricultural Service, Global Agriculture Information Network GAIN Report - SA7012, 2007.

[3] El-Shinnawy, M.M. The use of some by products in feed mixtures for feeding animals. Ph.D. Thesis, Cairo Univ., Fac. Agriculture, Cairo, Egypt, 1974.

[4] Dobbins, C.N. Jr. Biomeal, food waste converted into an animal feed ingredient. Off-Proc-Annu-Meet-Am-Assoc-Feed-Microsc, 22d:107-111, 1977.

[5] Anderson D C. Use of cereal residues in beef cattle production systems. Journal of Animal Science 46:849-861, 1978.

[6] El Shaer, H.M. Utilization of agriculture residues for animal feed. Proceedings of FAO Expert Consultation on the Utilization of Agricultural Residues. Cairo, Egypt, 6- 8 June, 2004, pp. 15 -28, 2004.

[7] El Shaer, H.M.; Attia-Ismail, S.A. and Kandil, H.M. Processing and feeding value of poultry manure as a feed ingredient for sheep. Egyptian J. Animal Production. 31: 121 - 133, 1994.

[8] Gabina, D. and El Shaer, H.M. Animal production technologies. Proceedings of the Final Seminar of the Regional Action Programme on Rainfed Agriculture (RAP-RAG) of the EC (Europe Aid) - CIHEAM Cooperation Project 1998 -2003, Zaragosa , Spain , 2-3 June , 2003, pp. $231-261,2003$.

[9] A.O.A.C. Association of official Analytical chemists: Official Methods of Analysis $\left(15^{\text {th }}\right.$ Ed) Washington, D.C., U.S.A., 1990.

[10] Jackson, M.L. Soil Chemical Analysis. Prentice Hall, New Delhi, pp.485, 1973.

[11] Wong, S.Y. and S.S. Lin. Composts as sol supplement enhance plant growth and fruit quality of straw berry. J. Plant Nutr. (25), 2243-2259, 2002.

[12] SAS. 1993. Institute, Inc., SAS/STAT, Guide for Personal Computers Versi. USA.

[13] Duncan, D.B. Multiple range and multiple. F. tests Biometrics. 1955.

[14] Church D. C. and W. G. Pond. Basic Animal Nutrition and Feeding ( $3^{\text {rd }}$ Ed.). John Wiley \& Sons, New York. 1982.

[15] Kearl. I.C. Nutrient requirements of ruminants in developing countries. Utah Agric. Exp. Sept. Utah State University, Logan, USA. 1982.

[16] Samuel, OBI, K.C. Aflatoxins levels in laboratory animal diet components. Zbl. Vet. Med. B, 25: 174- 177, 1978.

[17] Youssef, K.M., Askar, A.R. and El Shaer, H M. Effect of feeding nonconventional concentrates as a feed block supplement on performance of Shami goats in North Sinai, Egypt. Proc. Regional Workshop on Recent 
420 The Sustainable World

Advances in Goat Production Under Arid Condition, April 10 -13, 2006, Cairo, Egypt, pp 37- 45, 2006.

[18] El-Shaer H.M.; H.M. Kandil; H.S Khamis and H.M. Abo E1-Nasr. Alternative feed supplement resources for sheep and goats in Egypt. Proceedings of Seminar on Recent Advances in Small Ruminant, Rabat, Morocco, pp. 15 - 20, 1996. 